\title{
FIRST LANGUAGE INFLUENCE ON NON-NATIVE SPEAKERS' BUSINESS WRITING: A CROSS-CULTURAL STUDY
}

\begin{abstract}
Communication and socialization skills are a necessity in contemporary business community. If business professionals are not able to express their ideas clearly, concisely, and appropriately, it will be challenging for them to close international business deals and agrrements. In this context, bilateral trade and economic relations between Kazakhstan and other countries have been growing steadily over the past years. This paper focuses on the first language influences that may lead to communication breakdown and cross-cultural pragmatic failure as seen in the corpora of 200 business letters written in English by Kazakhstani business professionals to their international partners.
\end{abstract}

KEYWORDS: business letters, business professionals, communication breakdown, pragmatic failure, cross-cultural analysis, effective business communication.

1 aimoldina_aa@mail.ru

This paper was submitted on August 5, 2017 and accepted for publication at the meeting of the Editorial Board held on September 19, 2017. 
Today, with the increased globalization of the world economy and the internationalization of business contacts, there is an obvious turn towards cross-cultural studies of business communication and business discourse (Bargiela-Chiappini and Nickerson, 2003; Gibson, 2005; Palmer-Silveira \& al., 2007; O'Rourke \& Tuleja, 2008, etc.). Particularly, the issues of effective business writing as the key element in successful international business relations between business partners (Pilegaard, 1997; Wang, 2010; Incelli 2013; Suleimenova and Burkitbayeva, 2009; Burkitbayeva, 2005, etc.) are of special significance in linguistic studies both in Kazakhstan and abroad. Cross-cultural professional communication among business community members assumes a proper mutual communicative behavior which leads to the development of mutually beneficial professional cooperation. It requires appropriate discursive competences and the ability to understand the viewpoint of business partners belonging to different sociocultural strata of the international business community. Therefore, in-depth analysis of language variations in a particular setting such as written cross-cultural business communication, where interaction is expected to be precise and concise, has been brought to prominence.

As many scholars postulate, sometimes the cultural norms of the first language writing conventions are transferred to the second language resulting in pragmatic failure (Ziran and Zhuang, 1986; Ya and Ling, 2002; Ya, 2001; Zamborlin, 2007; Zhenbin, 2007, etc.), i.e., miscommunication and misunderstandings or "the failure to the inability to understand what is meant by what is said" (Thomas, 1983, p. 91). It is noted that lingua franca communication is particularly susceptible to pragmatic failures, because the participants' command of the language is imperfect, "there is little intersubjectivity, or certainty about sharedness, and the speakers' linguistic imperfections are likely to diverge from each other's" (Mauranen, 2011, p. 239). Thomas identifies two types of pragmatic failure, i.e., pragmalinguistic failure and sociopragmatic failure. In most cases pragmalinguistic failures occur "when speech act strategies are inappropriately transferred from L1 to L2", whereas sociopragmatic failures are "the result of a failure to identify a situation correctly" (Umale, 2005, p. 20). 
This finding mirrors similar findings from numerous interlanguage studies which show that these cross-cultural communication breakdowns may have both social and economic consequences, i.e., a decline in work satisfaction, interpersonal conflicts, racial tension, a drop in productivity, and even retrenchment (Clyne, Ball and Neil, 2011). In addition, improper interpretation of business messages may lead to the failure of business transactions, waste of financial assets, or legal responsibility. For instance, according to the ELISE (1996-1998) and the ELUCIDATE (1999-2000) projects' results, the lack of cross-cultural skills of the European trade managers are one of the main reasons for a large business loss (Hagen, 2001). Some researchers (Black, Gregersen and Mendenhall, 1992; Adler, 2002; Ferraro, 2010) believe that communication breakdowns in cross-cultural settings are mostly caused by the inability to decode and recognise "different ways of thinking and behaving, rather than by inadequate professional practice (Garcia-Yest, 2013, p. 197).

The overall aim of this study is to detect reasons for communication breakdowns and pragmatic failures in business letters in English written by Kazakhstani business professionals to their international business partners. The study aims to explore possible reasons for identified pragmalinguistic and sociopragmatic failures determined by vastly different cultural expectations in communication.

In this paper we shall first introduce the reader with the research methodology and the main findings of the analysis in relation to the communication strategies used by Kazakhstani business professionals. Extracts will be taken from the corpora to illustrate the most obvious examples. This article will end in examination of relevant limitations and suggestions for further research and study in conclusion.

\section{METHODOLOGY}

We have analysed a corpus of business letters in English written by Kazakhstani business professionals from international, national, and foreign companies to their native English-speaking business partners. These business letters were written during the period of three years, from January 2013 to December 2016. The pragmatic failures and different types of communication breakdowns were 
identified qualitatively from contrastive text linguistic and pragmalinguistic perspectives. The corpus comprizing 200 business letters was selected from a larger corpus comprizing 400 letters from four financial, five manufacturing, and five service companies located in Astana, Almaty, Atyrau, and Aktau.

\section{RESULTS AND DISCUSSION}

All business letters examined in the present study involved topics related to the business context in which these participants interact. These letters are generally institutionally sanctioned because in some cases they force the interlocutor to do something that he/she would not originally do. The results of the present study indicate that the business professionals' letters can easily put these specialists out of status as they often fail to see deference principles and tend to assume compliance on the part of the addressee (Brown and Levinson 1978, 1987).

Based on the existing classifications of the main causes of communication breakdowns (Blum-Kulka and Olshtain, 1986, Thomas, 1983 et al.), the following factors of pragmatic failures (which are relevant for this study) have been identified, i.e. the lack of business professionals' language skills; national and cultural differences of business communicators, i.e. cognitive aspects of each business communicator (belonging to different national cultures), and various pragmatic factors (discursive failures).

The present study found a number of examples which demonstrate discrepancies in the business communication participants' cultural and linguistic background, which make the communication process more complicated. In this research, a pragmatic failure applies to, on the one hand, misunderstandings between people who failed to decode the meaning of their interlocutor's statements, and, on the other hand, the construction of statements out of context, situation and traditions of a particular cultural and linguistic space that occurred between people from different speech communities (Charlebois, 2003).

Using direct strategies in this kind of business correspondence such as request letters, or inquiry letters, which are atypical of the English-language business correspondence, can lead to pragmatic failures and communication breakdowns since the recipient may regard this statement rude and too straightforward. In such kind of 
asymmetrical business communication, the principles of deference politeness (Brown and Levinson, 1987) of native speakers of English are usually shown through the imposition, sufficient mitigation, and a preference for conventional indirectness (Economidou-Kogetsidis, 2011). As shown in the example below, the Kazakhstani managers used a quite categorical request form, which led to the pragmatic failure:

Dear, [Full Name]!

I want you to send me the documents right now.

Dear [First Name]!

Immediately send an invitation with the cost of tuition and accommodation.

In the examples above the statements sound inappropriate and impolite to the English language speakers due to their directness, e.g. "Immediately send an invitation" without the marker "please" as a mitigator, sounds like an order, or a demand rather than a request. Correspondingly, the use of words "right now" or "immediately" instead of "at your earliest convenience", which is a conventional stable phrase in English business correspondence, adds a tone of impoliteness to the letter. In other examples of the examined business letters, different direct questions have been used, which are not typical for the English-speaking business communicators, e.g. "Did you get my visa application?", "I need to know...", or elliptical sentences: "any news?", "any comments?", etc. This might be due to different cultural background and a lack of linguistic competence of Kazakhstani business professionals. Although such business messages in the Kazakh and Russian language are acceptable, they can lead to pragmatic failures in the English business communication. This can be seen in the reply letter, where the English-speaking business professional responded in accordance with the accepted standards of his/her business culture:

Dear [Full name],

Thank you for your email. Please be reminded that it usually takes about two weeks to process business visa applications. In certain cases, visa processing times can be completed in two days at additional cost of 100\$. Should you decide to have your visa application processed faster, please make an online payment (See payment instructions in the Payment section on the Embassy site). Once the payment is made, scan the receipt and send it to this email address. Please, also include the address of the nearest DHL office in your city of 
residence where you would like your passport to be delivered for pick-up should your visa is granted.

Sincerely,

\section{[Full Name]}

Following the rules of writing in Kazakh and Russian business correspondence, there was the improper use of the exclamation mark and comma after the salutation ("Dear, [Full Name]!"). In business English writing, a comma is not put before and after the addressee's names, while the exclamation mark is rarely seen unless it is a letter to a close friend "Hey you!" or "Hey [First name]!". In business British English, the greeting is always followed by a comma, e.g., "Dear [First name]," while in the American-English language, only a personal letter has a comma after the recipients name, while a business letter has a colon, e.g., "Dear [First name]", but "Dear Mr. [Last Name]:".

The current study, however, further investigated the forms of address that Kazakhstani business professionals use in their letters to business partners. These pragmatic failures may not always lead to communicative breakdowns, but can be seen as rather abrupt and disrespectful by native speakers of English. The results indicated that business professionals' correspondence exhibited a wide stylistic range in form of address. The forms of address ranged from no salutation to more formal "Dear + title + [Last Name]". These findings show that the omission of the word "Dear" and zero form of address can easily lead to pragmatic failure in this asymmetrical business communication.

Here are some more examples:

- Misuse of social and professional status of the recipient, for example, "Mrs." instead of "Dr.";

- Use of only the recipient's first name, such as "Dear Dr. John" after the title (full name of the addressee is John Clark);

- Mentioning social and professional status of the recipient, such as "Dear Mr. Director", etc.;

- Use of particular greetings (e.g., Hello, Hi, Good afternoon, etc.), which are atypical of formal business correspondence in English business culture;

- Absence of greetings in general. 
In the examined business correspondence there were also cases of addressing business partners by using different distance strategies. As shown in the example of the first letter Kazakhstani business manager greeted the head of the representative office by using the form "Dear [First name]", and then in subsequent letters the manager suddenly decided to use a politer way of address by writing "Dear Mr. [Last name]" to avoid being seemingly distant. This can also be the cause of misunderstanding and communication breakdown because in some cases people distance themselves from people they do not want to do business with and who they do not trust.

A number of business letters written by Kazakhstani business professionals also show the improper use of active and passive voice. The use of the passive voice is very common in the English language, especially in a strained business correspondence to maintain a friendly tone. In some business texts written by Kazakhstani business professionals, the use of active voice has been reported in constructing sentences according to the generally accepted traditions of writing business letters, e.g. "You promised to complete the project outline within a week, and you have put us to considerable inconvenience through the long delay".

Despite the fact that the meaning of the claimed business message is clear for the English-speaking business professionals, it still causes some communicative discomfort. This communicative dissonance happened due to the fact that this communication was considered inappropriate from the perspective of the native English speaker. Taking into consideration features of English business culture, it is more appropriate to use the passive voice, e.g. "The project was promised to be completed within a week, and we have been put to considerable inconvenience through the long delay". In this case, the focus is on the problem itself, and not the people responsible for this issue. It is obvious, that the message is less direct. However, more information is needed to understand this and draw definite conclusions on how these constructions are perceived by native speakers in business settings, respectively.

In business correspondence, one of the stumbling blocks are phrases "in future/in the future" which are frequently used in business correspondence. However, when non-native business professionals talk about the future, they need to choose the right expression and not confuse the two phrases, which are different because of the definite article "the". Thus, the phrase "in future" 
means "from now on and always". It regularly appears in the context of communication between superiors and employees to express perceptions about their subordinates' behavior or performance, e.g., "Please be more careful with the numbers in future", i.e., from this moment and always. As for the phrase "in the future", it means "at/ from some future point in time", i.e. "We plan to undertake significant changes at the marketing department in the future", i.e., at some point in the future.

Double negatives (or negative concord) in business letters have also been identified as a cause of communication breakdowns. For example: "The preliminary agreement concluded by our organizations will be considered invalid in case no money is not be transferred to our bank account by 15 November". The meaning behind this sentence is this: "The preliminary agreement concluded by our organizations will be considered invalid in case the money is not transferred to our bank account by 15 November". However, because of the double negation used "no money is not transferred", which was literally translated from the business professional's first language, according to the rules of the English grammar, the recipient of such statement understands everything the other way around: "The preliminary agreement concluded by our organizations will be considered invalid in case the money is transferred to our bank account by 15 November ".

For example, in some languages like Spanish, Polish, Hungarian, Kazakh, and Russian, the negative concord (or double negation) is specifically used to enhance negation while it does not exist in languages like English and German. Moreover, it affects the meaning of the proposal and creates the opposite effect. This problem is one of the most widespread in the business world (where the meaning should always be clearly expressed) and occurs predominantly among those professionals whose native language allows a double negation. For example, in Russian, this is perfectly acceptable in business correspondence: "If we do not get no money, we terminate the agreement", but in English you can write this sentence with only one negation: "If we do not receive the payment, we will terminate the agreement" or "If we receive no payment, we will withdraw from the agreement".

The results additionally indicated that irrelevant deatils in the content of business letters can also lead to misunderstandings. Despite the fact that in specific business correspondence a special focus is on the essential details of the subject matter, not all mentioned details are always relevant for the context: 


\section{Good afternoon, dear [Full Name]!}

Having a gas processing facility in the Kyzylorda region, "[Company Name]" LLP has proceeded to business, where one of the raw materials is a fraction of pentane-hexane.

Due to the fact that your organization has developed ILI Kazakh ready standard organization "pentane-hexane fraction» ST TOO 165-1943-07-012011, we wrote an official letter to the website of "[Company Name]" LLP ref. Number 101 of 13 July 2012 with a request to give your permission to use the above mentioned standard by our organization, but the answer is still not received.

Please send us a formal response to our request.

Sincerely,

[First Name]

This text contains business syntactic constructions difficult for the English-speaking business professionals. Actually in one sentence several communicative tasks are included: 1) to inform the addressee about running for operation of a gas processing facility; 2) to inform the addressee about the lack of response to the previous request. In contrast, English business letters differ by simplified syntactic constructions and simplicity of style. Effect of perception is achieved by breaking down complex business text into separate, simple in composition and construction of phrases.

CONCLUSION This article deals with pragmatic failures detected in the examined business letters written by Kazakhstani business professionals in English in cross-cultural business settings. Most of the cross-cultural communication breakdowns we have examined stem from pragmatic and discourse rules and not grammatical and/or phonological problems.

The present study conducted for the purpose of this article also confirms the increasingly expanding role of the English language in Kazakhstani business communication, particularly in written business communication. It examined forms of address, the degree of directness employed, and the types of structures used by business professionals to achieve their communicative intentions. The results of the study indicate that business correspondence of Kazakhstani business specialists exhibits differences in communicative, pragmatic, rhetorical, graphic and stylistic aspects when compared to the one used by native speakers of English. Non-native speakers of the English language, particularly Kazakhstani business 
professionals, frequently make mistakes in interpreting the expectations of their business partners and understanding of the cultural context.

These findings have also been confirmed by various researchers (Bhatia 1993; Zhu 2005) asserting the fact that non-native speakers of English should have good awareness of national and cultural features of different writing conventions. Therefore, the basis of language structure is also a question of sociocultural structure. Overcoming a language barrier is not enough to ensure effective communication between people of different cultural background. It is necessary to overcome the barrier of national and cultural differences as well, since linguistic identity and symbolic semantics are formed in a particular socio-cultural space that defines worldviews, beliefs and values.

In this research, we have identified three reasons for pragmatic failures in written business correspondence: 1 . an intertwinement of different national and cultural standards; 2) a mixture of different functional styles; 3. authors' lack of knowledge of English (spelling, grammar, lexical errors). As the results of the study show, the main reason was usually the first one - an intertwinement of national and cultural standards that leads to misconceptions and misunderstandings about the writer's intentions and vice versa. Accordingly, specificity of drafting the text of business correspondence at the level of the composite scheme of communication strategies and tactics together with the pragmatic structure of the text, has a significant impact on the effectiveness of written business communication.

In conclusion, the results confirm the need for intensive teaching of written business communication at the institutions of higher education in Kazakhstan.

REFERENCES Bargiela-Chiappini, F., \& Nickerson, C. (2003). Intercultural business communication: A rich field of studies. Journal of Intercultural Studies, 24(1), 3-15.

Bhatia, Vijay K. (1993). Analysing Genre: Language Use in Professional Settings. London: Longman.

Blum-Kulka, S., \& Olshtain, E. (1986). Too many words: Length of utterance and pragmatic failure. Studies in second language acquisition, 8(02), 165-179.

Brown, P., \& Levinson, S. (1978). Universals in language usage: politeness phenomena. In: E. Goody (Ed.), Questions and Politeness (pp. 56-289). Cambridge: Cambridge University Press. 
Brown, P., \& Levinson, S. (1987). Politeness: Some Universals in Language Usage. Cambridge: Cambridge University Press.

Burkitbayeva, G. G. (2005). Business Discourse: Ontology and Genres [Деловой дискурс: онтология и жанры]. Almaty: Gylym.

Charlebois, J. (2003). Cross-cultural pragmatic failure and language teaching. JALT Hokkaido.

Clyne, M., Ball, M. \& Neil, D. (2011). Intercultural communication at work in Australia: Complaints and apologies in turns. In: Zhu Hua (Ed.), The language and Intercultural Communication Reader (pp. 311-325). Oxon: Routledge.

Economidou-Kogetsidis, M. (2011). "Please answer me as soon as possible": Pragmatic failure in non-native speakers'e-mail requests to faculty. Journal of Pragmatics, 43(13), 3193-3215.

Gibson, R. (2005). Intercultural business communication. TESL-EJ, 9(1).

Incelli, E. (2013). Managing discourse in intercultural business email interactions: a case study of a British and Italian business transaction. Journal of Multilingual and Multicultural Development, 34(6), 515-532.

Mauranen A. (2011). Signalling and preventing misunderstanding in English as Lingua Franca communication. In: Zhu Hua (Ed.), The language and Intercultural Communication Reader (pp. 239-256). Oxon: Routledge.

O’Rourke, J., \& Tuleja, E. (2008). Module 4: Intercultural Communication for Business (Vol. 4). Cengage Learning.

Palmer-Silveira, J. C., Ruiz-Garrido, M. F., \& Fortanet-Gomez, I. (2007). Intercultural and international business communication. TESL-EJ, 11(1).

Pilegaard, M. (1997). Politeness in written business discourse: A textlinguistic perspective on requests. Journal of Pragmatics, 28(2), 223-244.

Suleimenova, E. D., \& Burkitbayeva, G. G. (2009). Kazakhstan. The Handbook of Business Discourse (pp. 436-453). Edinburgh: Edinburgh University Press.

Wang, J. (2010). Convergence in the rhetorical pattern of directness and indirectness in Chinese and US business letters. Journal of Business and Technical Communication, 24(1), 91-120.

Zhu, Y. (2005). Written Communication across Cultures: A sociocognitive perspective on business genres. Amsterdam: John Benjamins Publishing Company. 


\begin{abstract}
АлИјА АИмолдИНА
ОДЕЉЕЊЕ МОСКОВСКОГ ДРЖАВНОГ УНИВЕРЗИТЕТА ЛОМОНОСОВ У КАЗАХСТАНУ, АСТАНА, КАЗАХСТАН
\end{abstract}

РЕЗИМЕ

УТИЦАЈИ МАТЕРЮЕГ ЈЕЗИКА НА ПОСЛОВНУ КОРЕСПОНДЕНЦИЈУ НА СТРАНОМ ЈЕЗИКУ: КУЛТУРОЛОШКО ИСТРАЖИВАҢЕ

Вештине комуникације и социјализације су обавезне у савременој пословној заједници. Немогућност изражавања и преношења идеја јасно, концизно и на одговарајући начин отежава постизање договора са позитивним исходом у међународној пословној сарадњи. Билатерална трговина и економски односи између Казахстана и других земаља су се протеклих година континуирано развијали. Овај рад се бави утицајима матерњег језика, који могу довести до прекида у комуникацији и до културолошких прагматичких пропуста, на основу корпуса од 200 пословних писама на енглеском језику послатих из Казахстана међународним пословним партнерима. Анализирани су случајеви који јасно показују знатна неслагања између културолошког и језичког контекста говорних јединица, а која компликују комуникациони процес. Рад приказује разлоге прекида у комуникацији и прагматичке пропусте у пословној коресподенцији укључујући више различитих културолошких стандарда структурног и лингвистичког процесуирања пословних писама, мешавину различитих жанрова у једном пословном тексту са више комуникативних циљева, недостатак језичких вештина у пословној коресподенцији на енглеском језику и слично.

КљУчнЕ РЕчи: успешна пословна комуникација, интеркултурална анализа, прагматички пропусти, прекид у комуникацији, пословни свет, пословна кореспонденција.

Овај чланак је објављен и дистрибуира се под лиценцом Creative Commons Ауторство-Некомерцијално Међународна 4.0 (CC BY-NC 4.0 |

https://creativecommons.org/licenses/by-nc/4.0/).

This paper is published and distributed under the terms and conditions of the Creative Commons Attribution-NonCommercial International 4.0 licence (CC BY-NC 4.0 | https://creativecommons.org/licenses/by-nc/4.0/). 